\section{Technology}

Timber Technicalities: Definitions of Terms used in the Timber and Correlative Trades and Wood Consuming Industries. By Edwin Haynes. Second edition, revised and enlarged by Thomas J. Stobart. Pp. vii +184 . (London : Ernest Benn, Ltd., 1933.) 8s. 6d. net.

THIs book is a dictionary of terms used by foresters, timber merchants, agents, shippers, sawyers and others engaged in the cultivation and felling of trees, and in the sale and manipulation of timber. Although many of the terms are given in other dictionaries, their collection and arrangement in a book of convenient size for carrying about is a very distinct gain for the business people for whom it is primarily intended. It was originally published in 1921, and this, the second, edition has undergone some considerable revision.

In addition to the many terms described, there is a very useful list of contractions and abbreviations of terms used in the timber and shipping trades many of which have little significance to the uninitiated. Instances are, c.m., calliper measure ; f.a.q., fair average quality ; f.o.w. (Baltic trade), first open water; a/s, alongside ; d.b.b., deals, battens and boards. There is also a comparative table of actual and nominal measurement of planed goods showing the gain for freight; a list of average weights per cubic foot of seasoned home-grown timber; a list of average weights of green and dry American lumber; a glossary of timber trade technical terms in English, French, German, Spanish and Swedish. Thus, in one of the terms of inferior quality timber we have English, Inferior Fifths ; French, Rebut ; German, Ausschuss; Spanish, Madera muy Ordinaria ;
Swedish, Utskott. A bibliography of works on forestry completes the volume.

Der Glaszustand. Von Gustav Tammann. Pp. 123.

(Leipzig : Leopold Voss, 1933.) 8.70 gold marks.

GLass is unique in that it differs from ordinary crystalline solids on one hand and from liquids on the other. Some consider that in a descriptive sense it should be associated with supercooled liquids; others think that the lack of crystalline form in glasses is only apparent. The X-rays appear to disclose orderlinass of atomic arrangement on a scale far too fine for the microscope ever to reveal.

Prof. Tammann's book brings under review a great deal of work carried out in his own laboratories at Göttingen during the last few years and forms an admirable appendix to his well-known book on "Aggregatzustände". The discussion of the properties of ordinary glasses of the silicate type is incidental rather than of set purpose. One of the main objects of the book is the presentation of the general properties of glass in the so-called softening range. For this reason the properties of substances such as piperin, selenium and salipyrin, not usually dealt with by the ordinary glass technologist, come under review. Viscosity, elasticity, volume-pressure relations, crystallisation velocity and refractive index phenomena are amongst some of the subjects discussed. An item of particular interest to physicists is the question of molecular rotation in the softening range.

The book is well produced and, within the limits prescribed by the author, of considerable value to all who are interested in the properties and constitution of substances which may exist in a vitreous form.

\title{
Forthcoming Books of Science
}

Agriculture, Forestry and Horticulture

Edward Arnold and Co.-British Economic Grasses, Sydney Burr and Dorothy Turner. Cambridge University Press.-The Foundations of Agricultural Economies, Dr. J. A. Venn. Country Life, Ltd.-The Care and Repair of Ornamental Trees, A. D. C. Le Sueur. McGraw-Hill Publishing Co., Ltd.--Back to the Land for a Living, A. Durgee. Herbert Jenkins, Ltd.-Earnest Earth, Elsie Grey Turner. Thomas Murby and Co.-The Methods of Examining the Soil, Physical and Chemical, C. H. Wright. John Murray.-Trees and Shrubs hardy in the British Isles, W. J. Bean. Oliver and Boyd, Ltd.-Agriculture, the Science and Practice of British Farming, Prof. J. A. S. Watson and James A. More; Practical Animal Husbandry, W. C. Miller and Major E. D. S. Robertson. Oxford University Press. - 'Meria Laricis': The Leaf Cast Disease of Larch, T. R. Peace and C. H. Holmes; Open Air Dairying, R. N. Dixey and M. Messer; The Culture and Marketing of Tea, C. R. Harler.

\section{Anthropology and Archæology}

Cambridge University Press.-Religious and Cosmic Beliefs of Central Polynesia, R. W. Williamson. Chapman and Hall, Ltd.-A Short History of Ancient Egypt, Arthur Weigall. J. M. Dent and Sons, Ltd.-The Archæology of Herod's Temple, Dr. F. J. Hollis. George G. Harrap and Co., Ltd.-Myths and Legends of the Bantu, Dr.
Alice Werner. Jackson, Wylie and Co.-The Roman Fort at Cadder, John Clarke. Jarrolds, Ltd.-The Conquest of the Maya, J. Leslie Mitchell. John Long, Ltd.-Love through the Ages, Diana Strickland. Sampson Low, Marston and Co., Ltd.-The God of the Witches, Dr. Margaret A. Murray. Luzac and Co.-New Approach to the Vedas: an Essay in Translation and Exegesis, Ananda K. Coomaraswamy; Islamica and Arabica, U. Wayriffe. Macmillan and Co., Ltd.--Pagan Survivals in Mohammedan Civilisation, Dr. E. Westermarck. Methuen and Co., Ltd.-Romanian Furrow, D. J. Hall ; The Old Straight Track, A. Watkins. John Murray. -Christian Myth and Ritual, Dr. E. O. James; Gods, Heroes and Men of Ancient Greece, Dr. W. H. D. Rouse. Oxford University Press.-The English Folk-Play, E. K. Chambers; Everyday Life in Ancient Greece, C. E. Robinson; Celtic Ornament in the British Isles down to A.D. 700, E. T. Leeds; A Pageant of Asia, K. J. Saunders ; European Civilization: its Origin and Development, edited by Edward Eyre. George Routledge and Sons, Ltd. -Malekula: a Vanishing People in the New Hebrides, A. Bernard Deacon, edited by Camilla H. Wedgwood.

\section{Biology}

George Allen and Unwin, Ltd.-Experimental Bacteriology, W. Kolle and H. Hetsch, edited by Dr. John Eyre; Exploring the Animal World, Charles Elton. Edward Arnold and Co.-Heredity and the Social Problem Group, 